\title{
South African Artillery in the Eighties
}

\section{Sgt AC Lillie*}

Emerging from the Second World War armed with the then completely adequate 25 pounder and BL 5.5" guns, the South African Field Artillery continued to use the same guns operationally over thirty years later.

When the armed forces of South Africa were thrown into a conventional conflict during the Angolan Civil War in 1975, the gunners found their equipment to be woefully inadequate. Soviet made artillery systems in the hands of the Russian-backed forces possessed ranges far in excess of the Second World War vintage South African systems and brought home in a very real way the need for drastic modernisation of the artillery branch of the South African Army.

Resulting from the need which had been realised, ARMSCOR has succeeded in harnessing the most advanced thinking in the field of artillery and ammunition production with the resultant taking into service of the G-5 gun/howitzer which is superior in range to any of the systems currently being used by NATO forces. Growing out of this development, and as an answer to specific South African needs the G-6 high mobility self-propelled gun has subsequently been developed exclusively in South Africa.

\section{G-5: The development}

Once the need for more modern artillery had been identified, ARMSCOR was faced with the problem of where and how to obtain the necessary technology. The answer came in the shape of Space Research Corporation of Quebec (SRC-Q), a Canadian company which had for some years been conducting research aimed at achieving significantly greater artillery ranges than were possible at the time. This research focussed on both long barrels and ammunition designated ERFB (Extended Range Full Bore) These two factors combined to produce a weapon system with a maximum range in excess of $30000 \mathrm{~m}$, a considerably better range than that of NATO gun/howitzers

Having acquired a minority shareholding in SRC-Q, ARMSCOR set to work with the company and together they began with the development of an artillery system designed specifically for South African needs. Through its connections with the Belgian ammunition firm PRB, SRC (and through it, ARMSCOR) gained access to the concept of 'base bleed' which when combined with ERFB technology enabled guns to achieve ranges which until then had not been obtainable. While SRC concerned itself with efforts to market its $155 \mathrm{~mm}$ gun/howitzer, the GC45, internationally, ARMSCOR continued with the development of its gun.

Two guns were manufactured by SRC in 1979 and after trials in both Canada and on the Island of Antigua, they were transferred to South Africa to serve as models for series production. The South African connection with SRC-Q was subsequently discovered and led to the imprisonment of the company's President, Dr Gerald Bull, for contravening the UN arms embargo.

\section{G-5 - The Gun}

Consisting of the gun/howitzer itself, a complete range of ammunition, gun tractor, meteorological station, muzzle velocity analyzer, artillery computer, artillery helmet and radio communication system, the G-5 system is now in service with Artillery units of the South African Artillery.

The breech which is of the interrupted screw type with cam-operated semi-automatic action opens automatically when the barrel assembly returns to battery and to close automatically when the cam is swung out of engagement. The ramming and loading system is based on a swing aside loading tray mounted on the rear cradle of the recoil system so that it moves in elevation with the cannon assembly. A pneumatically operated and manually controlled telescopic ramming cylinder is rotated into place behind the projectile for loading at high elevation angles. This arrangement makes it possible for reloading to be performed at any given barrel elevation, dispensing with the need to lower the gun between shots for ramming. The semi-automatic breach action and the pneumatic rammer allow a maximum rate of fire of 3 rounds/minute with a sustained rate of fire of 2 rounds/minute.

The carriage consists of a split-trail configuration with built-in tow bar and the trail lifting wheel assemblies are located at the outboard rear of 
each trail, in order to assist the gun crew during emplacement and displacement operations. The pivoted trail spades have four pre-set positions and can be spread to a maximum angle of $84^{\circ}$. The undercarriage comprises a walking beam suspension system (with two wheels per side), allowing high towing speed and greater mobility under tow in rough terrain

The trails, trail wheels and firing platform have hydraulic servos which are powered by a $68 \mathrm{hp}$ air-cooled diesel engine which also provides a limited amount of self-propulsion ( $8 \mathrm{kph}$ on hard ground and $3 \mathrm{kph}$ on sand). Using hydraulic power to spread/close the trails, raise/lower/ steer the wheels and raise/lower the firing platform, allowing the crew of five to bring the G-5 into action in two minutes.

A later addition to the $\mathrm{G}-5$ is a device for the continuous measurement of the muzzle velocity. Designated EMVA Mk. 10B, the system can measure muzzle velocities to an accuracy of $\pm 0.05 \%$, in the range $30 \mathrm{~m} / \mathrm{sec}$ to $3000 \mathrm{~m} / \mathrm{sec}$. The gun is usually towed by the SAMIL 100 gun tractor which enables it to travel at speeds of up to $90 \mathrm{kph}$.

\section{G-6 Self-Propelled Gun}

Although the provision of the G-5 gave the artillery much-needed fire support, it still failed to meet the need for a highly mobile support system which was able to be rapidly deployed in distant border areas.

Because of this need which still existed, ARMSCOR began with the development of a self-propelled gun designed specifically to meet South African requirements. Although western self-propelled guns such as the M109, SP.-70 and GCT are all tracked vehicles, the South African Army has a requirement for a weapon system which can keep pace with infantry and armoured car units participating in pre-emptive strikes, which invariably require long distances to be covered. A gun on a tracked chasis would obviously provide major problems regarding the speed of mechanised columns. However, more than this, the vast distances involved in the Southern African conflict make it desirable for a weapon system of this nature to be highly mobile so that it is not necessary for tank transporters to be used to bring the system to just behind the front line as is common practice in other theatres.

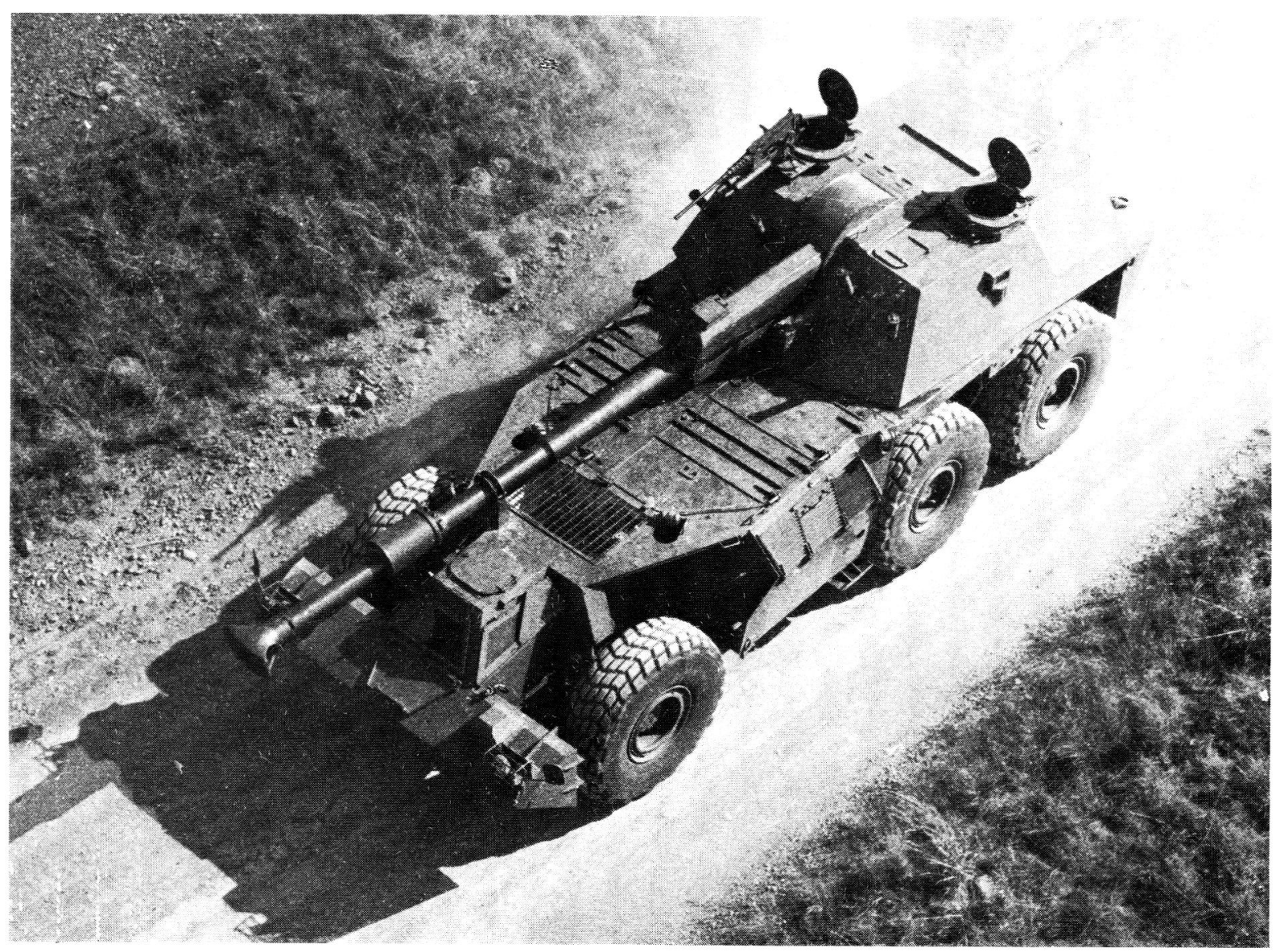

The RHINO G-6 self-propelled gun 
Owing to the specific need as outlined above, ARMSCOR opted for a wheeled vehicle for its self-propelled gun. The G-6 uses the same ordnance as the G-5 and was in fact designed to suit the gun with the result that because no limitations were placed on the size of the turret by an already existing chasis, the crew have more than adequate space for comfortable operating conditions.

Known as the Rhino, the G- 6 has a mass of $36 \mathrm{t}$, is $10 \mathrm{~m}$ long and $3,25 \mathrm{~m}$ wide. To decrease the ground pressure presented by its considerable weight, the vehicle has enormous $21 \times 25$ runflat tyres, which make movement over sand easier therefore providing the much sought-after mobility.

The turret is fully traversable, but firing by way of the semi-automatic loading system which enables a rate of fire of 4 rounds/minute is only possible on a frontal arc of $40^{\circ}$ on each side. Emphasis has been placed on protection for the crew of five (commander, driver, gunner, loader and ammunition handler) with firing ports to enable small arms to be used against ambushes. Besides this, the Rhino has been designed to withstand mines and this includes blow-out holes which allow the blast to be vented upwards.

Powered by a air-cooled turbocharged diesel engine, the G-6 is capable of speeds in excess of $90 \mathrm{kph}$ on a road and $45 \mathrm{kph}$ cross-country. Operational range is over $400 \mathrm{~km}$.

\section{Ammunition}

A special range of ammunition which can be used in both the G-5 and G-6 (and in fact most $155 \mathrm{~mm}$ guns) is now being produced by ARMSCOR. Using the ERFB round which is a very long and streamlined projectile, ARMSCOR has produced five types of ammunition. These are High Explosive (HE), High Explosive Base Bleed (HEBB), Smoke (SMK), illuminating (ILLUM) and White Phosphorous (WP). With a payload mass of $8,7 \mathrm{~kg}$ the Base Bleed round has a range of $37500 \mathrm{~m}$ at sea level, although far greater distances have been achieved under ideal conditions (up to $45000 \mathrm{~m}$ ).

Besides the increased ranges which are possible with ERFB rounds, an added advantage is the larger internal volume which enables a larger and more dense explosive filling to be carried. This together with the use of high-fragmentation steel gives excellent terminal effects.

\section{Bibliography}

Bonsignore, E. 'G-5 and G-6: South Africa does it (almost) by itself' Military Technology Vol 7, No 11983

Boyle, R. 'South Africa Starts Arms Export Drive' International Defense Review 3/1983

Dodd, NL. 'South African Artillery Re-equipped' Journal of the Royal Artillery September 1983

Lillie, AC. 'An alternative view of South African Artillery' Militaria 13/1, 1983

'Die unieke G6' Paratus October 1982

* Sgt AC Lillie is attached to the Military Information Bureau, SADF 